Piotr Rosiak

Uniwersytet $w$ Biatymstoku

\title{
REALIZACJA ZASADY SŁUSZNOŚCI W RAMACH ŚWIADCZENIA WYRÓWNAWCZEGO
}

Zasada słuszności, nazywana niekiedy zasadą sprawiedliwości moralnej lub zasadą ,prawości”, jako reguła, która łagodzi skutki rygorystycznie stosowanej zasady równego traktowania (zasady sprawiedliwości formalnej) oraz bezpieczeństwa obrotu w imię słuszności, przenika współczesne prawo prywatne zarówno unijne, jak i krajowe. W polskim prawie prywatnym podstawową konstrukcją wprowadzania elementów słuszności są klauzule generalne. Odsyłają one do kryteriów leżących poza systemem prawa i mają charakter subiektywnie dokonywanej oceny w zależności od konkretnego stanu faktycznego. Wyróżnienie w nich elementów obiektywnych jest mało skuteczne, a i jednocześnie niepotrzebne. Przykładem takiej klauzuli są chociażby „zasady współżycia społecznego”, czy też „,względy słuszności”. Zasada słuszności $\mathrm{w}$ prawie prywatnym przejawia się również w szczegółowych rozwiązaniach normatywnych, które pozwalają na korygowanie i modyfikację rygorystycznych, ogólnych rozwiązań prawnych. Jako przykład takich rozwiązań wskazać tu można konstrukcję wyzysku (art. 388 k.c.), czy zasadę rebus sic stantibus (art. $357^{1}$ k.c.), która modyfikuje regułę pacta sunt servanda. Do tej grupy zaliczyć również należy instytucję świadczenia wyrównawczego korygującą pewne elementy konstrukcyjne umowy agencyjnej, takie jak zasady wynagradzania i odpowiedzialności stron wynikających $\mathrm{z}$ tego stosunku prawnego po jego ustaniu.

\section{Zasada słuszności jako uzasadnienie dla roszczenia o świadczenie wyrównawcze}

W praktyce obrotu tak bardzo skomplikowana instytucja roszczenia wyrównawczego odgrywa ogromne znaczenie. Trzeba jednak podkreślić, że jej charakter prawny, jak i szczegółowe zagadnienia związane z dochodzeniem tego roszczenia nie zostały w pełni w piśmiennictwie wyjaśnione. Dotyczy to nie tylko piśmiennictwa polskiego, co zresztą - z uwagi na krótką historię świadczenia wyrównawczego 
w naszym prawie - nie powinno budzić wątpliwości, ale przede wszystkim doktryny niemieckiej, w którym ma ono najdłuższą tradycję. ${ }^{1}$

W literaturze niemieckiej podnoszono, że charakter prawny świadczenia wyrównawczego może być rozumiany różnorodnie. Po pierwsze możliwe jest przyjęcie koncepcji, wedle której roszczenie wyrównawcze ma na celu wynagrodzenie szkód, które zostały poniesione przez agenta wskutek zakończenia umowy, polegających na utracie możliwości uzyskiwania prowizji z transakcji ze zdobytymi przez niego klientami. Mogłoby mieć one zatem charakter odszkodowawczy (rekompensacyjny). Po drugie można argumentować, że instytucja ta może zostać ujęta jako uprawnienie agenta do wynagrodzenia powstające po zakończeniu umowy, przysługujące w zamian za przejęcie, czy też korzystanie przez dającego zlecenie z przekazanej przez agenta pozyskanej klienteli. Stanowiłoby więc rodzaj wynagrodzenia. Wreszcie możliwe jest wyjaśnienie natury prawnej roszczenia wyrównawczego poprzez doszukiwanie się podobieństwa do kondycji funkcjonujących w ramach instytucji bezpodstawnego wzbogacenia. ${ }^{2}$

Przenosząc rozważania o naturze świadczenia wyrównawczego na grunt polskiego prawa prywatnego przede wszystkim należy mieć na względzie orzecznictwo. Sąd Najwyższy w wyroku z dnia 29 września 2011 r. stwierdził: „Roszczenie wyrównawcze nie ma cech (funkcji) roszczenia odszkodowawczego i roszczenia obejmującego jakąś postać szczególnego wynagrodzenia, powstającego dopiero ex lege po zakończeniu stosunku agencyjnego. Nie można tu też mówić o szczególnie ukształtowanym bezpodstawnym wzbogaceniu (art. $405 \mathrm{KC}$ )". ${ }^{3}$

Stanowisko Sądu Najwyższego należy uznać za prawidłowe. Podstawy do dochodzenia przez agenta roszczenia odszkodowawczego należy upatrywać w przepisach kodeksu cywilnego, dotyczących odpowiedzialności kontraktowej, a w pewnych wypadkach nawet odpowiedzialności deliktowej. Roszczenia wyrównawczego nie można utożsamiać z roszczeniem odszkodowawczym w żadnej z tych postaci. Jest to uregulowanie wyjątkowe, wykraczające zdecydowanie poza zasady odpowiedzialności kontraktowej, gdyż rozwiązanie umowy agencyjnej nie stanowi w żadnej mierze nienależytego wykonania umowy ze strony dającego zlecenie. Rozwiązanie stosunku agencyjnego jest $\mathrm{w}$ tym przypadku zgodne $\mathrm{z}$ prawem, jak również często z postanowieniami samej umowy. Nie można mówić tu również o odpowiedzialności deliktowej, ponieważ opiera się ona na zupełnie innych przesłankach niż roszczenie o naprawienie szkody - aktualizuje się niezależnie od powstania szkody oraz winy dającego zlecenie. Analizowane roszczenie nie jest również roszczeniem $\mathrm{o}$ wynagrodzenie. Bowiem dla jego ustalenia $\mathrm{w}$ dużym stopniu mają znaczenie za-

\footnotetext{
1 Zwracają na to uwagę E. Rott-Pietrzyk, W. Klyta, Świadczenie wyrównawcze przysługujące agentowi - nowa instytucja w prawie polskim, Kwart. Pr. Prywatnego, Rok XIII: 2004, z. 3, s. 776

2 Tak ibidem, s. 776 i przywołana tam literatura.

3 Wyrok SN z 29.09.2011, IV CSK 650/10.
} 
sady słuszności, stąd też agent nie uzyskuje przedmiotowego roszczenia m.in., jeżeli sam bez odpowiedniej przyczyny wypowiedział umowę.

W tym samym wyroku Sąd Najwyższy stwierdził, że roszczenie wyrównawcze jest oryginalnym, samoistnym roszczeniem przysługującym mu niezależnie od innych roszczeń majątkowych powstałych w czasie trwania stosunku agencyjnego lub po jego ustaniu. Na taki charakter zwrócono uwagę również w doktrynie. ${ }^{4}$ Jednakże nie zauważono, iż jego podstawą, uzasadnieniem egzystencjalnym jest zasada słuszności. Istnienie tego roszczenia wynika z tej klauzuli generalnej na takiej samej zasadzie, jak powstaje odpowiedzialność odszkodowawcza oparta na zasadzie słuszności. Tak jak w przypadku odpowiedzialności odszkodowawczej nie wynikającej z zasady winy i ryzyka decydują względy słuszności, tak i tu nie można znaleźć regulacji, na której można byłoby oprzeć roszczenie o świadczenie wyrównawcze, jak tylko na zasadzie słuszności.

\section{2. „Względy słuszności” jako klauzula generalna}

Artykuł $764^{3} \S 1$ k.c. in fine stanowi, iż roszczenie wyrównawcze przysługuje agentowi, jeżeli biorąc pod uwagę wszystkie okoliczności, a zwłaszcza utratę prowizji od umów zawartych przez dającego zlecenie z tymi klientami, przemawiają za tym względy słuszności. Na gruncie odpowiedzialności odszkodowawczej zasadę słuszności utożsamia się z ideą sprawiedliwości. W większości sytuacji, gdy obowiązek odszkodowawczy oparty jest na zasadzie słuszności, ustawodawca bezpośrednio określa jednak przesłanki tej odpowiedzialności w przepisie. Jedynie w nielicznych przypadkach kodeks cywilny nie precyzuje tych przesłanek, pozostawiając możliwość zasądzenia odszkodowania ocenie sędziego, ze względu na szczególne, towarzyszące wyrządzaniu szkody okoliczności. Przy czym w przypadku roszczenia odszkodowawczego względy słuszności, jako podstawa sędziowskiej oceny, zostały zastąpione w kodeksie cywilnym zasadami współżycia społecznego. Nie wydaje się jednak, by rozstrzygając o istnieniu w danym przypadku roszczenia o świadczenie wyrównawcze, celowe było odwołanie się do zasad współżycia społecznego. Gdyby tak w rzeczywistości było, to ustawodawca powołałby się na tę klauzulę generalną. Celowo zatem zrezygnowano z tej formy redakcyjnej przepisu na rzecz właśnie względów słuszności. Dlaczego tak się stało, wyjaśnił Sąd Najwyższy: „Nie chodzi o (...) okoliczności dotyczące agenta osobiście, jak wiek, sytuacja zdrowotna czy rodzinna itp., ale o okoliczności ściśle związane z umową agencyjną". ${ }^{5}$ Odwołanie się do klauzuli generalnej oznaczałoby zatem konieczność uwzględnienia nie tylko okoliczności obiektywnych odnoszących się do samej umowy, ale tych okoliczności subiektywnych, które wiążą się z osobą agenta i jego sytuacją osobistą. Zatem 
odwołanie się w przepisie do klauzuli generalnej w postaci względów słuszności pozwala na elastyczne podejście do konkretnego stanu faktycznego i uwzględnienie jego szczególnych okoliczności, ale tylko w zakresie odnoszącym się do stosunku prawnego łączącego obydwie strony. Stąd też należy formułować wniosek, iż w kontekście tego przepisu względy słuszności powinny wiązać się raczej z zasadami uczciwego obrotu, pozwalającego uwzględnić sytuację obu stron stosunku umownego, a zwłaszcza fakt, że agent działa w zakresie swego przedsiębiorstwa.

Zaistnienie przedstawionych wyżej przesłanek nie przesądza automatycznie, że sąd pozytywnie ustosunkuje się do żądania agenta zasądzenia stosownego świadczenia wyrównawczego. Oceniając bowiem zasadność roszczenia o świadczenie wyrównawcze niezbędne jest, jak wynika z powyższego, uwzględnienie czynnika natury słusznościowej. Biorąc pod uwagę wymagane względy słuszności w piśmiennictwie formułuje się wnioski co do potrzeby elastycznego podejścia do konkretnego stanu faktycznego i uwzględnienia specyfiki danej sytuacji. ${ }^{6}$ Wyjaśnia się w związku z tym, że utrata przez agenta prowizji od transakcji z klientami, o których mowa $\mathrm{w}$ art. $764^{3} \S 1$ k.c. nie jest jedynym zdarzeniem, którego zaistnienie przemawia za przyznaniem agentowi wyrównania ze względu na zasady słuszności. Z tego punktu widzenia nader istotne znaczenie ma więc użyte w zdaniu drugim tego przepisu słowo „Zwłaszcza”.

Pamiętając, że świadczenie wyrównawcze nie ma charakteru odszkodowawczego i stanowi szczególny rodzaj przysporzenia na rzecz byłego agenta znajdujący uzasadnienie w zasadach słuszności, koniecznym jest podjęcie próby ustalenia, jakie okoliczności należy uwzględnić dla rozstrzygnięcia istnienia $\mathrm{w}$ danym przypadku roszczenia o świadczenie wyrównawcze przy uwzględnieniu zasad uczciwego obrotu. W raporcie Komisji Europejskiej dotyczącym stosowania art. 17 dyrektywy przewidującym obowiązek wprowadzania do ustawodawstw krajowych przepisów o świadczeniach związanych z faktem wygaśnięcia agencji, wymienia się następujące okoliczności: prowadzenie przez agenta działalności dla innych podmiotów, staranność przy wykonywaniu umowy, wzrost obrotów dającego zlecenie, korzyści osiągnięte przez dającego zlecenie, istnienie klauzuli zawierającej zakaz konkurencji. ${ }^{7}$ Ogromne znaczenie miało w tym zakresie stanowisko Sądu Najwyższego, który w przytaczanym już wyroku z dnia 8 listopada 2005 r. stwierdził: „Rozwiązania zastosowane $\mathrm{w}$ dyrektywie przejęte zostało z prawa niemieckiego ( $\$ 89 \mathrm{~b}$ niemieckiego kodeksu handlowego), a wypracowana przez sądy tego państwa praktyka orzecznicza znajduje szerokie zastosowanie przy wykładni pojęcia «znaczne korzyści» przez instytucje państwowe i polecana sądom innych państw członkowskich w przedstawionym przez Komisję (...) raporcie (...). Regulacja zawarta w art. $764^{3}$ $\S 1$ kc., przejmująca konstrukcję świadczenia wyrównawczego, jest niemal wier-ordination of the laws of the Member States Relating to self-employed commercial agents (86/653/EEC), s. 3. 
nym powtórzeniem art. 17 dyrektywy. Orzecznictwo sądów polskich nie wykształciło dotychczas kryteriów precyzujących pojęcie «znaczne korzyści». W doktrynie podjęto natomiast próby wyjaśnienia tego pojęcia i przedstawiono rozstrzygnięcia sądów innych państw, w szczególności sądów niemieckich, które - jak wynika ze wskazanego wyżej raportu - nie może być pominięte przy wykładni przepisów krajowych". Zdaje się zatem, że bezkrytycznie przyjęto wykładnię nie tylko zwrotu „znaczne korzyści” z orzecznictwa innych państw, ale również innych pojęć użytych w przepisie, przede wszystkim ,względów słuszności”. Wynika to z poglądów prezentowanych w późniejszym czasie przez doktrynę. Za uznaniem, iż okoliczności te postrzegane przez pryzmat zasady słuszności w całości mają przełożenie na grunt polskiego prawa prywatnego jest chociażby E. Rott-Pietrzyk. ${ }^{8}$ Autorce wtóruje T. Wiśniewski, którego zdaniem na ocenę żądania świadczenia wyrównawczego rzutuje również działalność agenta na rzecz konkurenta, bez względu na fakt, czy stanowi to naruszenie umowy, czy też nie. ${ }^{9}$

Pewnym jest, że wykazanie wszystkich okoliczności in abstracto jest niemożliwe. Nie wydaje się jednak, by wszystkie powyżej wskazane okoliczności rzeczywiście musiały wpływać na ocenę istnienia roszczenia o świadczenie wyrównawcze. Okoliczności te należałoby ograniczyć jedynie do tych, które mają związek z relacją kontraktową pomiędzy dającym zlecenie a agentem. Można powiedzieć, że roszczenie przysługiwać będzie agentowi o tyle, o ile ustalimy, że dotychczasowe wynagrodzenie agenta, otrzymane $w$ ramach umowy agencyjnej, pozostaje $w$ dysproporcji do faktycznych korzyści, jakie z pracy świadczonej przez agenta otrzymuje dający zlecenie. Należy oczywiście uwzględnić, że pewna dysproporcja korzyści płynących dla agenta i dającego zlecenie z zawartej umowy agencyjnej jest jej immanentną cechą. Względy słuszności wymagałyby zatem porównania istniejących standardów rynkowych w zakresie wysokości prowizji wypłacanych agentom w zależności od czasu trwania umowy. Bez znaczenia dla roszczenia o świadczenie wyrównawcze jest natomiast to, czy agent świadczy pracę na rzecz innych podmiotów. Istnienie roszczenia o świadczenie wyrównawcze w żadnym bowiem razie, jak wskazywano wyżej, nie powinno być uzależnione od okoliczności związanych z sytuacją życiową danego agenta, gdyż świadczenie wyrównawcze nie może zmierzać np. do polepszenia sytuacji agenta, w jakiej znalazł się on po rozwiązaniu umowy. Jak wskazano wyżej, względy słuszności muszą być w tym wypadku rozumiane jako zasady uczciwego obrotu, sprowadzające się do zadośćuczynienia agentowi za jego wkład na poczet korzyści osiąganych przez dającego zlecenie. W żadnym zaś razie zadośćuczynienie to nie może być środkiem pomocy na rzecz agenta, który przestał świadczyć usługi na rzecz dającego zlecenie. Jedyny wyjątek należałoby uczynić w przypadku, gdy

8 E. Rott-Pietrzyk, (w:) System Prawa Prywatnego, Prawo zobowiązań - część szczegółowa, t. 7, red. J. Rajski, Warszawa 2011, s. 697.

9 T. Wiśniewski, (w:) Kodeks cywilny. Komentarz, t. 3, cz. 2, Zobowiązania, red. J. Gudowski, Warszawa 2013 s. 727 . 
w rozwiązanej umowie agencyjnej znajdują się klauzule konkurencyjne uniemożliwiające świadczenie usług agencyjnych na rzecz innych podmiotów. Tego typu postanowienia stwarzają bowiem rzeczywiste ograniczenie możliwości prowadzenia działalności gospodarczej przez agenta. Chyba że agent otrzymał w tym przypadku stosowne odszkodowanie.

Równie krytycznie należałoby podejść do próby łączenia względów słuszności z oceną staranności, z jaką agent wykonywał umowę. Przesłanki warunkujące powstanie roszczenia o świadczenie wyrównawcze powinny mieć charakter obiektywny. Jeżeli umowa nie została rozwiązana przez dającego zlecenie z powodu jej nienależytego wykonania przez agenta, to badanie staranności, z jaką była wykonywana, po jej rozwiązaniu, w celu ustalenia prawa do ewentualnego świadczenia wyrównawczego, należy uznać za chybione. Można nawet zaryzykować stwierdzenie, że w sytuacji, gdy z umów zawartych przez agenta wynikają znaczne korzyści, większe niż w podobnych sytuacjach, bez znaczenia jest stopień staranności, z jaką taki agent wykonywał umowę.

Stąd też należy wnioskować, iż okolicznościami o charakterze generalnym, które z punktu widzenia zasad słuszności są przede wszystkim: wynikająca z treści przepisu utrata przez agenta prowizji od umów z tymi klientami oraz wzrost obrotów dającego zlecenie, a także korzyści przez niego osiągnięte. Są to okoliczności, jakie należy brać pod uwagę przy rozstrzyganiu o istnieniu roszczenia o świadczenie wyrównawcze, bowiem tylko one są związane z łączącym strony stosunkiem agencyjnym. Za takim zapatrywaniem przemawia również wykładnia językowa art. $764^{3}$ $\S 1$ k.c.

Wskazanym wyżej okolicznościom można nadać charakter pozytywny. Ich wykazanie przez agenta przemawiać będzie za istnieniem w konkretnym przypadku względów słuszności, co z kolei będzie uzasadnieniem jego roszczenia o świadczenie wyrównawcze. $Z$ kolei niemoc ich udowodnienia skutkować będzie oddaleniem powództwa $\mathrm{z}$ uwagi na brak elementów słusznościowych. Zadać jednak należy pytanie, czy wystarczającym jest wykazanie tylko okoliczności o charakterze pozytywnym, ażeby móc stwierdzić, że względy słuszności przemawiają za zasądzeniem świadczenia wyrównawczego. Z punktu widzenia byłego agenta na pewno tak. Jednakże czy druga strona stosunku agencyjnego, a więc dający zlecenie może przywołać okoliczności, które również z punktu widzenia zasad słuszności przemawiałyby za niezasądzaniem tego świadczenia.

W doktrynie powszechnie przyjmuje się, że nie byłoby uzasadnione względami słuszności wypłacenie agentowi świadczenia wyrównawczego, np. w sytuacji, gdy: w czasie trwania umowy agencyjnej dający zlecenie partycypował w kosztach organizowania lub rozwoju przedsiębiorstwa agenta, a po rozwiązaniu umowy agencyjnej przynosi to agentowi nadal wymierne korzyści; dający zlecenie pokrywał wydatki związane z działalnością agenta w kwocie wyższej niż ta, do której był zobowiązany; dający zlecenie pokrywał koszty kampanii reklamowych w takim zakre- 
sie, że pozwoliło to osiągnąć korzyści samemu agentowi; dający zlecenie pokrywał koszty szkoleń, dzięki którym agent uzyskał dodatkowe kwalifikacje i w dalszym ciągu czerpie z tego korzyści. Ponadto wskazuje się, że ocenie powinien także podlegać stopień wynagradzania dotychczasowych wysiłków agenta poprzez wypłaconą prowizję. ${ }^{10}$ Charakter tych okoliczności należy określić jako negatywny. Takie względy słuszności przemawiać będą za odmową uwzględnienia żądania agenta. Jednakże, czy występowanie tych okoliczności ma jakikolwiek wpływ na ocenę spełnienia przesłanki.

Jednoznaczną interpretację zdaje się można znaleźć w wyroku Sądu Najwyższego z dnia 8 listopada 2005 r. Sąd Najwyższy stwierdza bowiem, że: „ciężar wykazania, iż względy słuszności przemawiają przeciwko zasądzeniu świadczenia wyrównawczego, spoczywają na pozwanym, podczas gdy rzeczą skarżącej jest wykazanie okoliczności świadczących na jej rzecz, a więc przesłanek pozytywnych". Wątpliwości budzi natomiast stwierdzenie Sądu Najwyższego, że roszczenie o świadczenie wyrównawcze nie ma charakteru powszechnego. Zestawienie ze sobą tych wypowiedzi nakazuje sformułować następujące pytanie - skoro roszczenie to nie ma charakteru powszechnego, to po co dający zlecenie powinien wykazywać okoliczności negatywne? Za zasadnością pytania przemawiają również względy redakcyjne przepisu. W zdaniu drugim ustawodawca wyraźnie zastrzegł, że względy słuszności muszą ,przemawiać za”. Gdyby ustawodawca chciał, ażeby decydujące znaczenie miały okoliczności negatywne, inaczej sformułowałby treść przepisu - ,jeżeli nie sprzeciwiają się temu względy słuszności”. Tymczasem brzmienie przepisu jednoznacznie wskazuje, że względy słuszności stanowią pozytywną przesłankę dla roszczenia o świadczenie wyrównawcze. Przysługuje ono bowiem tylko wtedy, gdy istnieją znaczne korzyści po stronie dającego zlecenie i jest to uzasadnione względami słuszności, a więc tylko okolicznościami o charakterze pozytywnym. Wykazanie zatem również i tej przesłanki należy do powoda, zgodnie z ogólną regułą dowodową wynikającą $\mathrm{z}$ art. 6 k.c. $Z$ drugiej strony nie bez znaczenia może pozostawać fakt, że korzyści, które dający zlecenie nadal otrzymuje z klienteli zdobytej przez byłego agenta wynikają w znacznej mierze z nakładów poczynionych przez niego na rzecz przedsiębiorstwa agenta. Zdaje się jednak, że te okoliczności powinny być uwzględniane dopiero na etapie określania wysokości roszczenia.

W związku z powyższym trudno jednoznacznie określić funkcję tej klauzuli generalnej. Dopuszczając możliwość wykazania okoliczności negatywnych pozwoliłoby to na formułowanie wniosku o funkcji korygującej. Wpływałaby bowiem na istnienie w ogóle roszczenia o świadczenie wyrównawcze w danym, konkretnym stanie faktycznym. Powyższe ustalenia jednak nakazują przyjęcie ograniczonego za-

10 I. Mycko-Katner, Umowa agencyjna, Warszawa 2012, s. 246; E. Rott-Pietrzyk, Agent handlowy - regulacje polskie i europejskie, Warszawa 2006, s. 73; P. Mikłasiewicz, (w:) Kodeks cywilny. Komentarz, t. 2, Zobowiązania, red. K. Osajda, Warszawa 2013, s. 1560; T. Wiśniewski, Umowa agencyjna według kodeksu cywilnego, Warszawa 2001, s. 168. 
kresu tej funkcji, mającej znaczenie dopiero na późniejszym etapie postępowania - ustalania wysokości świadczenia wyrównawczego.

\section{Konkluzja}

Na przykładzie instytucji świadczenia wyrównawczego, której pierwowzorem jest ustawodawstwo niemieckie widać, jak ogromne znaczenie nadaje się zasadzie słuszności w innych systemach prawa europejskiego. Coraz większą rolę zaczyna ona odgrywać również na gruncie prawa polskiego. Przewidywana nowelizacja kodeksu cywilnego w pewnym zakresie ma na celu zmianę podejścia do klauzuli zasad współżycia społecznego i zastąpienie jej na wzór prawa holenderskiego „rozsądkiem" jako kryterium prawnym występującym łącznie z klauzulą słuszności (,względy rozsądku i słuszności”). ${ }^{11} \mathrm{~W}$ prawie polskim ten proces już się zaczął, jednakże tylko w odniesieniu do instytucji relatywnie nowych, które w dużej mierze stanowią implementację rozwiązań przewidzianych w prawodawstwie unijnym.

Stąd też mechanizm wymiaru świadczenia wyrównawczego oparty jednocześnie na zwrotach niedookreślonych i klauzuli generalnej ma na gruncie naszego prawa charakter szczególny. Zasada słuszności odnajdująca się na gruncie tej regulacji w tak różnorodnej postaci oddaje w pełni jej esencję. 


\section{THE IMPLEMENTATION OF THE PRINCIPLE OF EQUITY IN THE CONTEXT OF INDEMNITY}

The subject of this publication is an analysis of the regulation contained in Article $764^{3}$ of the Civil Code in the context of the principle of equity. This regulation pertains to the indemnity, which is to be given to the agent after termination of an agency contract. Article $764^{3}$ of the Civil Code uses indeterminate terms and a general clause relating to the considerations of equity. This article shows how the principle of equity is realized in this clause and what the are terms. It also answers the question as to how they should be understood and interpreted on the basis of Polish civil law, if we take into account the principle of equity.

Keywords: indemnity, principle of equity, general clause 